\title{
Entre Honneth e Hegel: da liberdade À ETICIDAde eM O DIREITO DA LIBERDADE
}

\author{
Polyana Tidre ${ }^{1}$ \\ Inácio Helfer ${ }^{2}$
}

Resumo: O presente trabalho tem por objeto o retorno a Hegel proposto por Axel Honneth, em $O$ direito da liberdade. Ante as concepçóes de liberdade negativa e reflexiva - segundo ele, "conceitos de liberdade individual que não levam adequadamente em conta a sua dependência em relação à mediação objetiva” -, Honneth se preocupa em oferecer uma compreensão alternativa, mais larga, de liberdade, que ele nomeia, atribuindo-a diretamente a Hegel, de liberdade social. Tal liberdade, ao contrário da liberdade meramente jurídica ou moral, permitiria que se leve em conta o papel exercido pelas instituiçôes e práticas normativas para a sua realização, reconhecendo-as como sua própria condição. Entretanto, apesar da valorizaçáo que é feita assim por Honneth às instituiçōes, o autor é criticado por apresentar uma concepção das mesmas que seria demasiado unilateral. O mesmo ocorre com sua definição de "liberdade social", a qual remeteria, segundo os críticos, a uma liberdade meramente individual, aquém da significação que lhe seria dada por Hegel. A análise da tese hegeliana acerca de uma eticidade imanente à esfera do mercado e às suas práticas, adotada também por Honneth, nos possibilitará avaliar não só os aspectos que os aproximam ou os separam, mas também a pertinência das críticas dirigidas a Honneth.

Palavras-ChavE: Liberdade. Instituiçóes. Corporação. Bildung. Eticidade.

\section{INTRODUÇÃO}

O objeto de estudo do presente artigo consiste na consideração das concepçóes hegeliana e honnethiana de liberdade, assim como das instituiçóes que as garantem, especialmente através da maneira como são expostas,

${ }^{1}$ Pós-doutoranda na Universidade do Vale do Rio dos Sinos (Unisinos), São leopoldo, RS - Bolsista PNPD e autora do livro Individuum und Sittlichkeit: Die Beziehung zwischen Allgemeinheit und Besonderheit in Hegels Grundlinien der Philosophie des Rechts, publicado em 2018 pela Wissenschaftlicher Verlag Berlin. E-mail: polyanatidre@gmail.com.

(iD) http://orcid.org/0000-0003-0144-2284

2 Professor na Universidade do Vale do Rio dos Sinos (Unisinos). Pesquisador produtividade em pesquisa do CNPq, São leopoldo, RS - Brasil - PQ CNPq 2. E-mail: inahelfer@gmail.com.

http://doi.org/10.1590/0101-3173.2020.v43n2.12.p215 
respectivamente, em Linhas fundamentais da filosofia do direito (1820) e em $O$ direito da liberdade (2011). O texto tem o objetivo maior de averiguar a pertinência da atualização realizada por Honneth do conceito hegeliano de liberdade como uma "liberdade social".

Para tanto, expomos, em um primeiro momento (1), a crítica de Honneth, inspirada em Hegel, às liberdades meramente jurídica ou moral, que se mostrará fundamental na proposta de um entendimento mais largo de liberdade. Em um segundo momento, no intuito de estabelecer pontos comuns ou de distanciamento entre os autores, apresentamos a caracterização feita por Hegel da vontade livre (2.1), seguida daquela feita por Honneth da liberdade social, à qual acrescentamos as críticas - que mostraremos como equívocas feitas ao filósofo por Ludwig Siep e Sven Ellmers (2.2). Posteriormente, expomos a compreensão honnethiana de uma eticidade anterior ao mercado, distinta da concepção de Hegel, que a entende como imanente (3.1), assim como sua defesa acerca da possibilidade de uma coexistência entre comportamento solidário e comportamento instrumental (3.2). Nós o fazemos, no intuito de demonstrar que, se é verdade que não estamos convencidos dos argumentos avançados por Siep e Ellmers, em relação a Honneth, cremos, não obstante, encontrar em sua concepção de liberdade e das instituiçóes que a possibilitam contradiçóes que acabam por enfraquecer justamente aquilo que a torna mais convincente, ante uma concepção meramente negativa de liberdade.

\section{De Honneth a Hegel: método de reconstruçáo normativa e Crítica Às LIBERDADES NEGATIVA E MORAL}

1. O direito da liberdade, obra publicada por Axel Honneth, em 2011, busca oferecer uma alternativa às teorias da justiça que, ancoradas seja na concepção de liberdade negativa, fundamentada na tradição dos jusnaturalistas e contratualistas (liberdade jurídica), seja na concepçáo de liberdade reflexiva dos moralistas - cujos fundamentos se encontrariam, segundo Honneth, na concepção de liberdade como autodeterminação, em Kant, e como autorrealização, em Herder -, se equivocariam, ao pressuporem "conceitos de liberdade individual que não levam adequadamente em conta a sua dependência em relação à mediação objetiva” (DL ${ }^{3}$, p. 110).

\footnotetext{
${ }^{3}$ HONNETH (2015).
} 
2. Através de um retorno a Hegel, cuja intenção seria, ao contrário, a "de esboçar uma teoria da justiça a partir de pressupostos estruturais" (DL, p. 19) graças a uma "reconstrução normativa", Honneth se propóe investigar, munido do mesmo método, analisando a realidade social contemporânea, quais as instituiçôes e práticas que, nos complexos éticos das relaçôes pessoais, econômicas e políticas - seguindo a divisão empreendida por Hegel, em sua Filosofia do direito -, contribuiriam à realização da liberdade.

3. Embora Honneth dispense o que ele chama de "fundamento metafísico" da filosofia hegeliana, ele intenta, portanto, se servir do método de $\mathrm{Hegel}^{4}$, que, em sua Filosofia do direito, se opondo simultaneamente à doutrina do direito natural (Naturrechtslehre) e à Escola Histórica do Direito (Historischer Rechtsschule) representada por Savigny, já defendia a importância do que ele denomina "método especulativo", o qual, através da exposição do desenvolvimento do conceito, deveria oferecer o critério através do qual se tornaria possível distinguir o "efetivo racional" do mero acidental e arbitrário (GW 14,1, especialmente Prefácio e Introdução) $)^{5}$. Segundo Walter Jaeschke (2003, p. 376), em face

\footnotetext{
${ }^{4}$ Honneth pretende renunciar ao "fundamento metafísico" ou à "ideia teleológica" do pensamento hegeliano, que, entretanto, como ele mesmo admite, desempenha um papel importante no próprio procedimento metodológico de Hegel de reconhecimento das instituições como racionais (Cf. DL, p. 113-114). Uma problematização da questáo é levantada por Filipe Campello (2013, p. 189), por Andreas Arndt (2015, p. 27-28), bem como por Sven Ellmers (2015, p. 119), segundo o qual Honneth abandona o "conceito idealista de Espírito" de Hegel, a ideia fundamental do Espírito objetivo - a não ser no "sentido fraco", de que as instituiçôes são objetivações de valores. Por conseguinte, Ellmers indaga: A questão que resta a responder é se tais valores "satisfazem a razão". Sobre a mesma temática, ver também Axel Honneth (2001, p. 11-13, 1992, p. 107-108) [ed. bras.: HONNETH, A. Sofrimento de indeterminação: uma reatualização da filosofia do direito de Hegel. Tradução de Rúrion Soares Melo. São Paulo: Singular/Esfera Pública, 2007] e a objeção levantada por Karin de Boer (2011, p. 161-178). Compare-se também Jean-François Kervégan, que aponta para as consequências negativas de se ler a Filosofia do direito, abrindo mão dos pressupostos remanescentes da lógica ou do sistema hegeliano: " $\mathrm{Si}$ d'éminents commentateurs continuent d'adopter le parti (ici qualifié de vieil hégélien) d'une lecture fidèle au programme systématique explicite du hégélianisme [...], d'autres, en nombre croissant, font le choix du jeune hégélien d'une lecture non métaphysique de Hegel, une lecture qui, de quelque manière qu'elle entende rompre avec la lettre du système, implique que soient écartées ou relativisées certaines des ambitions les plus fortes dont il était porteur, avec le risque évident de le priver ainsi de ce qu'il a de plus puissant." (2007, p. 9).

5 Cf. HEGEL, Georg Wilhelm Friedrich. Grundlinien der Philosophie des Rechts. In: Ders.: Gesammelte Werke, Bd. 14,1, hg. v. Klaus Grotsch u. Elisabeth Weisser-Lohmann. Hamburg: Meiner, 2009 [ed. bras.: HEGEL, G. W. F. Linhas fundamentais da filosofia do direito ou direito natural e ciência do Estado em compêndio. Tradução de Paulo Meneses, Agemir Bavaresco, Alfredo Morais, Danilo Vaz-Curado R. M. Costa, Greice Ane Barbieri e Paulo Roberto Konzen. São Leopoldo: Ed. Unisinos, 2010].
} 
da "mera abordagem histórica da História do Direito" ou, no extremo oposto, "um desenvolvimento do conceito de Direito que renunciaria completamente à história”, tratar-se-ia em Hegel, ao contrário, da perseguição de uma "terceira via", a qual consistiria na "via da reconstrução filosófica da realização do Direito".

Além do método, também a crítica de Honneth às liberdades jurídica e reflexiva, que introduzíamos acima, encontra correspondência na Filosofia do direito de Hegel, em seu tratamento da liberdade meramente negativa e daquela que ele atribui ao "subjetivismo" . Como Hegel, Honneth não se limita à crítica, mas se preocupa igualmente em mostrar o importante papel que desempenham tais concepçóes da liberdade: segundo Honneth, trata-se de liberdades ou direitos subjetivos que permitiriam ao indivíduo se recolher a uma esfera privada, de estabelecimento de valores e objetivos de vida, assim como de questionamento ou revisão da ordem social estabelecida ${ }^{7}$.

Entretanto, o recurso ao direito ou à reflexão, no processo de conformidade - ou de questionamento - às instituiçóes e práticas normativas, levantaria dificuldades a partir do momento em que tais liberdades são tomadas por absolutas, deixando-se de levar em conta o papel fundamental das instituições enquanto condição sem a qual essas liberdades não seriam possíveis. Dessa negligência das liberdades negativa e reflexiva, ante suas próprias condiçôes sociais, resultariam o que Honneth chama de "patologias da liberdade jurídica ou da liberdade moral", fundadas no equívoco de se "considerar a mera 'possibilidade' da liberdade como toda a sua 'realidade" (DL, p. 233, destaques do autor). Para ele, ao contrário, "as práticas normativas em ambas as esferas são em si incompletas, demandando complementação por relações da vida real" (DL, p. 233).

Remetendo à crítica de Hegel às teorias da justiça baseadas na tradição contratualista, segundo as quais um ordenamento social justo seria "resultado de um contrato social fictício ou de uma construção de vontade democrática" (DL, p. 109), Honneth sustenta a ideia de que os sujeitos participantes de tais deliberaçôes seriam portadores de uma liberdade "que eles não obteriam sem participar em instituiçôes que já são justas”. É "somente em instituiçôes

6 Cf. TIDRE, 2018, especialmente capítulo 2, "Hegels Kritik des Subjektivismus und der Naturrechtslehre".

7 Cf. DL, p. 117-119. Segundo Honneth, Hegel já daria assim espaço à possibilidade de "transgressividade" (DL, p. 117-118). 
socialmente justas, que garantam a liberdade dos sujeitos, [que] estes podem adquirir a liberdade individual que seria necessária para tomar parte em tais procedimentos" (DL, p. 109). Ter-se-ia de combater, portanto, a perspectiva de acordo com a qual os sujeitos seriam pensados como separados do mundo exterior dos dispositivos e das instituiçôes sociais (DL, p. 85), livres "já antes de toda e qualquer integração num ordenamento social"8.

Os modelos da liberdade reflexiva (tanto como autodeterminação quanto como autorrealização) incorreriam no mesmo erro, ao negligenciar as condições sociais possibilitando o exercício de tal liberdade:

Ao determinar a liberdade, são artificialmente deixadas de lado as condiçóes e formas institucionais que sempre deveriam aparecer ao se iniciar a reflexão, para levá-la a bom termo. É parte da mesma autodeterminação, de maneira mínima, como ainda outro momento, a condição social de que os objetivos morais estejam institucionalmente disponíveis, assim como a autorrealização tem de ser categoricamente pensada, uma vez que os bens que correspondem aos desejos encontram-se presentes da $[s i c]$ realidade social (DL, p. 80)9.

Assim, Honneth (DL, p. 80) conclui que "a ideia da liberdade reflexiva não se deixa desdobrar sem incluir as formas institucionais que possibilitam o seu exercício". Frente a essas duas concepçôes, Honneth pretende oferecer uma compreensão alternativa de liberdade, que ele chama, atribuindo-a diretamente a Hegel, de "liberdade social" (DL, p. 84), capaz de levar em conta o papel exercido pelas instituiçóes e práticas normativas na realização da liberdade, reconhecendo-as como sua própria condição.

\section{DA VONTADE LIVRE À LIBERDADE SOCIAL}

Distanciando-se das concepçóes de liberdade jurídica e reflexiva, Honneth introduz um conceito de "liberdade intersubjetiva" (DL, p. 86), a qual constituiria o "reconhecimento recíproco", por parte dos indivíduos, da "necessidade de complementaridade de seus respectivos fins" (DL, p. 86). A liberdade intersubjetiva consistiria, portanto, no fato de cada um reconhecer a contraparte como "condição da realização dos próprios desejos e fins" (DL, p.

\footnotetext{
8 "Se para alcançar a liberdade basta agir, seja sem restriçăo externa ou em atitude reflexiva, os sujeitos podem entấo ser pensados como suficientemente livres já antes de toda e qualquer integração num ordenamento social." (DL, p. 110).

9 No original: "In der gesellschaftlichen Realität vorhanden sind." (HONNETH, 2011/2017, p. 79).
} 
86). No entanto, Honneth logo argumenta sobre a necessidade de se adotar um conceito mais abrangente de liberdade, a "liberdade social" (DL, p. 86-87).

A interdependência evidenciada na definição de Honneth da liberdade intersubjetiva, de reconhecimento do outro como condição de satisfação dos meus próprios fins, lembra a caracterização que Hegel (GW 14,1, \$183) fazia da sociedade civil-burguesa como, segundo sua terminologia, um "sistema dos carecimentos" ou "sistema de dependência mútua", o qual, "condicionado pela universalidade", significa que "a subsistência e o bem estar do indivíduo e seu ser-aí jurídico se entrelaçam na subsistência, no bem estar e no direito de todos, aí se fundamentam e somente podem ser garantidos através dessa associação." Tal condição é definida por ele ainda como "Estado externo" ou "Estado da necessidade e do entendimento".

Através da dependência econômica e da divisáo do trabalho, o indivíduo se torna, na sociedade civil-burguesa, ao mesmo tempo que procura satisfazer seus próprios interesses, "membro de uma corrente", da qual ele participa e à qual ele contribui, por meio de seu próprio trabalho (GW 14,1, $\$ 187)$. Embora, como afirma Hegel, o elemento da universalidade, por esse entrelaçamento de necessidades, já se encontre aí presente, esta permanece, nessa situação de dependência mútua, somente uma universalidade formal ${ }^{10}$ ou mesmo "inconsciente" ${ }^{11}$. Aqui o outro ainda é visto tăo somente como meio, como constitutivo ou condicionante da minha liberdade, na medida em que dependo do mesmo para alcançar meus próprios interesses (GW 14,1, $\$ \$$ 183, 187, 189, 192 e 249).

Dando à liberdade intersubjetiva a caracterização aparentemente conferida por Hegel à relação de necessidade mútua do sistema dos carecimentos, Honneth oferece ainda um outro conceito de liberdade, segundo ele, mais amplo, o qual ele denomina "liberdade social", remetendo-o explicitamente a Hegel. A fim de podermos julgar a pertinência dessa remissão honnethiana - e de eventuais dificuldades que dela emergem -, faz-se necessária uma breve exposição da liberdade em Hegel, com destaque, em razão da nossa problemática, à sua distinção entre vontade livre e arbítrio.

\footnotetext{
${ }^{10}$ Cf. GW 14,1, $\$ 187$ ou ainda GW 14,1, $\$ 195$ : "Diese Befreyung ist formell, indem die Besonderheit der Zwecke der zu Grunde liegende Inhalt bleibt.” (grifo do autor).

${ }^{11}$ MÜLLER, 1965, p. 182: "In den besonderen Interessen innerhalb der bürgerlichen Gesellschaft ist das Allgemeine unbewußt enthalten.”
} 


\subsection{Vontade liVRe E ARbítrio EM Hegel}

$\mathrm{Na}$ introdução da sua Filosofia do direito, Hegel classifica o primeiro momento da vontade como a possibilidade de ser pura indeterminaçáo ${ }^{12}$. Essa capacidade da vontade, caracterizada por Hegel, nesse contexto, como "liberdade negativa ou do entendimento" (GW 14,1, \$5, Anotaçôes), é, como lembra Safatle (2012, p. 154), momento necessário na história do Espírito, determinação essencial da vontade, tornando possível a exigência à universalidade marcante nas reivindicaçóes veiculadas pela Revolução Francesa e materializada na Declaração dos direitos do homem e do cidadão ${ }^{13}$. Ainda que meramente abstrata, a primeira manifestação da universalidade na vontade se desenvolverá, ulteriormente, até a universalidade concreta mediada pelo Estado e suas instituiçóes. Conforme afirma Safatle (2012, p. 158, grifo do autor),

[...] a enunciação da universalidade concreta só é possível após a experiência da negatividade, pois ela pressupóe uma capacidade de abstraçáo e transcendência, uma indiferença às diferenças fundamental para a fundação da noção moderna de cidadão.

Entretanto, tomada aqui, não como momento, mas, unilateralmente, como o todo da vontade, cai num fanatismo (GW 14,1, $\$ 5$, Anotaçóes), o qual, no campo político, se traduz pela destruiçáo de toda ordem social dada - que Hegel (1970, \$5, Adendos) liga ao terror jacobino.

Assim como a capacidade de se abstrair de todo conteúdo, também a capacidade a se deixar determinar é intrínseca à estrutura da vontade. Segundo Safatle (2012, p. 152), ao contrário do primeiro momento da vontade, da pura indeterminação, que se fundamentaria na noção da autenticidade, esse segundo momento corresponderia a um modelo de liberdade "que hipostasia a noção de autonomia" (SAFATLE, 2012, p. 159), cujo resultado corresponderia a uma dicotomia entre ação moral e desejos. Essa noção de autonomia, advinda de Rousseau e retomada por Kant, se traduziria pela “[...] capacidade dos

\footnotetext{
12 "Der Wille enthält $\alpha$ ) das Element der reinen Unbestimmtheit oder der reinen Reflexion des Ich in sich, in welcher jede Beschränkung, jeder durch die Natur, die Bedürfnisse, Begierden und Triebe unmittelbar vorhandener oder, wodurch es sey, gegebener und bestimmter Inhalt aufgelöst ist; die schrankenlose Unendlichkeit der absoluten Abstraction oder Allgemeinheit, das reine Denken seiner selbst." (GW 14,1, \$5).

${ }^{13}$ Cf., por exemplo, Erklärung der Menschen - und Bürgerrechte, de 1791, cujo primeiro artigo proclama, evidenciando a reivindicação por liberdade e igualdade abstratas do direito: "Die Menschen sind und bleiben von Geburt frei und gleich an Rechten.” (FRANZ, 1964, p. 305).
} 
sujeitos [de] porem para si mesmos a sua própria Lei moral, transformandose assim em agentes morais capazes de se auto-governar" (SAFATLE, 2012, p. 159). Ou, ainda: "Esta lei [...] não é [...] uma lei particular, ligada aos interesses egoístas da pessoa privada. Antes, ela é incondicional, categórica e universal” (SAFATLE, 2012, p. 159). Ela seria, portanto, “[...] vontade pura que age por amor à universalidade da Lei. Vontade que se coloca como dever" (SAFATLE, 2012, p. 159, grifo do autor).

Também aí haveria uma pretensão à absolutização, à "perpetuação da moralidade sob a forma do dever" (SAFATLE, 2012, p. 160), consistindo no fato de não se querer abandonar a contraposição do homem como ele "ê" e do homem como ele "deve ser" (2012, p. 160) - crítica fundamental feita por Hegel ao formalismo que ele imputa à filosofia moral kantiana. Além de um primeiro sentido assumido pelo formalismo - segundo o qual "a fundamentação da ação moral através da pura forma do dever não é capaz de fornecer um procedimento seguro de decisão a respeito do conteúdo moral de minhas açôes" (SAFATLE, 2012, p. 160) -, o mesmo implica ainda uma desvalorização do conteúdo - as próprias instituições éticas (ELLMERS, 2015, p. 34) - pela qual a vontade é moralmente determinada, conteúdo que é assim percebido como heterogêneo a essa mesma vontade.

Isso levaria a uma dicotomia entre "a noção de causas exteriores" (SAFATLE, 2012, p. 163, grifo do autor) e "uma autonomia completamente internalista" ${ }^{14}$ que Hegel se interessa em combater. $\mathrm{Na}$ abertura da terceira parte da Filosofia do direito, sobre a eticidade, Hegel insiste que a substância ética não deve restar estranha ao sujeito ${ }^{15}$, e os "deveres" (GW 14,1, $\$ 148$ ), através dos quais a vontade se submete às "determinaçôes éticas" (GW 14,1, $\$ 148$, Anotaçôes), não devem ser vistos como limitação (Beschränkung, GW 14,1, $\$ 149$ ) dessa vontade, mas, antes, como "libertação" (Befreiung, GW 14,1,

\footnotetext{
14 “[...] a concepção moderna parece profundamente marcada pela oposição entre natureza e liberdade, causalidade externa determinada pela normatividade vital e causalidade interna determinada em condiçốes de autonomia" (SAFATLE, 2012, p. 160).

${ }^{15}$ Em GW 14,1, $\$ 147$, Hegel alude a "Selbstgefühl” - mesmo termo, aliás, usado nos Adendos do parágrafo 7, na análise sobre a amizade: "Hier ist man nicht einseitig in sich, sondern man beschränkt sich gern in Beziehung auf ein Anderes, weiß sich aber in dieser Beschränkung als sich selbst. In der Bestimmtheit soll sich der Mensch nicht bestimmt fühlen, sondern indem man das Andere als Anderes betrachtet, hat man darin erst sein Selbstgefühl. Die Freiheit liegt also weder in der Unbestimmtheit noch in der Bestimmtheit, sondern sie ist beides. [...] die Freiheit ist, ein Bestimmtes zu wollen, aber in dieser Bestimmtheit bei sich zu sein und wieder in das Allgemeine zurückzukehren.” (HEGEL, 1970) Para Honneth, a relação de amizade descrita nos Adendos serviria como um modelo paradigmático da experiência de uma liberdade buscando superar o formalismo kantiano (2001, p. 26-27).
} 
$\$ 149)$, tanto dos impulsos naturais quanto da subjetividade indeterminada "que não chega ao ser-aí e à determinação objetiva da ação" (GW 14,1, \$ 149).

$\mathrm{O}$ "dever" aqui corresponderia, portanto, à conformidade do indivíduo "às relaçóes a que pertence" (GW 14,1, \$ 150), que Hegel chama de "retidão" (Rechtschaffenheit), isto é, a virtude de se agir da maneira como se está "indicado, enunciado e conhecido" (GW 14,1, \$150, Anotaçôes). Isso permite a Hegel, segundo Adriaan Peperzak (2014, p. 177), superar a dualidade entre "a vontade particular e a vontade do todo" 16 , entre "a consciência moral e o Bom" (PEPERZAK, 2014, p. 177): "Enquanto a ação da vontade individual se conforma às relaçôes objetivas do todo (racional), ela é boa” ${ }^{17}$. É também nesse sentido que a vontade hegeliana se distingue da vontade como mero arbítrio. Como frisa Safatle, para Hegel, "a vontade que delibera, não delibera sob a forma do arbítrio" (SAFATLE, 2012, p. 162). Numa formulação mais controversa - pois, ainda que justa, mais aberta a desentendimentos - Safatle (2012, p. 162, grifo do autor) conclui que, para Hegel, "a liberdade não é uma questão de escolha individual".

O perigo de uma interpretação errônea de Hegel como aquele que se oporia à liberdade individual cresce, frente à leitura de trechos nos quais, fazendo uma distinção entre momentos objetivo e subjetivo da vontade (PEPERZAK, 2014, p. 169), Hegel ressalta, no seu combate ao subjetivismo, a primazia do todo ético como "substância concreta" (GW 14,1, \$144), "autoridade e poder" ( $\$ 146)$, perante a opinião subjetiva ou o arbítrio dos indivíduos, que ele designa como "acidentes" ( $\$ 145)$. Porém, em contraposição, da mesma maneira que o indivíduo precisa saber da eticidade como seu fundamento e fim (GW 14,1, $\$ 152)^{18}$, Hegel destaca igualmente que a substância ética é impensável sem o conhecer, o querer e o agir individuais ${ }^{19}$. Assim, o "dever"

\footnotetext{
${ }^{16}$ A tradução das passagens do artigo de Adriaan Peperzak, aqui citadas, são de autoria de Tidre.

${ }^{17}$ Indem sein Handeln [PT: des einzelnen Willens] sich den objektiven Verhältnissen des (vernünftigen) Ganzen fügt, ist es gut." (PEPERZAK, 2014, p. 177).

${ }^{18}$ Como lembra Peperzak, para Hegel, a mais alta realidade da liberdade corresponderia a uma eticidade como "bem vivente", e mesmo, à maneira de Aristóteles, em dois sentidos: como fundamento (archê) e como fim, o qual coloca tudo em movimento (telos), em vez de um ideal moral abstrato (à maneira do summum bonum kantiano) (PEPERZAK, 2014, p. 168).

${ }^{19}$ Sobre a importância da superação, para Hegel, de uma relação substância-acidentes, na qual a primeira usufruiria de um status ontológico maior, e diante da qual os segundos seriam depreciados, superação tornada possível através da valorização dada por Hegel à "manifestaçâo" que, na Doutrina do conceito, Hegel identificaria à própria liberdade; ver KLOTZ, 2017, em especial p. 127: "Quando na Filosofia do Direito Hegel fala da 'substância ética', descrevendo os indivíduos como seus 'acidentes', devemos entender isso no sentido de uma maneira (problemática) de acentuar o caráter objetivo e
} 
imposto ao indivíduo, de se comportar da maneira esperada pelo todo ético, se torna - na medida em ele sabe que, o fazendo, sua particularidade é não só respeitada, mas mesmo garantida por esse todo (GW 14,1, $\$ 261$, Anotaçôes) ${ }^{20}$ - ao mesmo tempo um "direito" (GW 14,1, \$152). Há aí, por conseguinte, uma correspondência entre "dever" e "direito" (GW 14,1, \$261, Anotaçóes), ou ainda, entre "dever" e "querer": as regras ditadas pelas instituições éticas não seriam mais compreendidas como algo que o indivíduo escolhe em detrimento daquilo que ele quer, através de uma capacidade de autodeterminação na qual a escolha pela ação justa se daria por meio de uma repressão de suas próprias paixões ou vontade. Ao contrário, em Hegel, haveria uma identidade entre o objeto dos impulsos ou paixóes e o objeto da ação moral ${ }^{21}$, adotado assim pelo indivíduo como "sua própria coisa particular" (GW 14,1, \$261, Anotaçóes).

Com isso, Hegel seria capaz de escapar ao formalismo segundo o qual as determinaçôes estruturantes do mundo social ético seriam percebidas como vindas "de fora" ou "de cima", às quais a consciência moral teria de se subjugar, de maneira relutante (PEPERZAK, 2014, p. 175). A essa consciência moral arbitrária Hegel opóe uma consciência moral ética (PEPERZAK, 2014, p. 186-188), como uma disposição de espírito (Gesinnung) de querer aquilo que, presente nas leis, instituiçóes e costumes, seria bom em si e por si (GW 14,1, $\$ 137)^{22}$.

orientador que as normas éticas possuem para os indivíduos, e não no sentido de uma recaída nas estruturas da Doutrina da Essência. A substância ética, como Hegel diz já na Fenomenologia do Espirito, é a 'obra' do querer e do agir dos indivíduos, não sendo, com isso, nenhuma 'substância' em sentido ontológico." Nesse mesmo sentido, Hegel se oporia às concepçôes que "baseiam-se na ideia de algo 'interior' que se mostra na exterioridade da qual ele ao mesmo tempo difere ontologicamente por possuir uma identidade própria e imediata."

20 "Das besondere Interesse soll wahrhaft nicht bey Seite gesetzt oder gar unterdrückt sondern mit dem Allgemeinen in Uebereinstimmung gesetzt werden, wodurch es selbst und das Allgemeine erhalten wird. Das Individuum, nach seinen Pflichten Unterthan, findet als Bürger in ihrer Erfüllung den Schutz seiner Person und Eigenthums, die Berücksichtigung seines besonderen Wohls, und die Befriedigung seines substantiellen Wesens, das Bewußtseyn und das Selbstgefühl, Mitglied dieses Ganzen zu seyn, und in dieser Vollbringung der Pflichten als Leistungen und Geschäfte für den Staat hat dieser seine Erhaltung und sein Bestehen."

${ }^{21}$ A valorização dos impulsos naturais que, de acordo com Safatle, é empreendida por Hegel, está ligada ao processo de se "redescobrir a história no interior da natureza. Isso significa mostrar como os impulsos são, na verdade, a parte não-individuada da história dos sujeitos, da história dos desejos que lhes precederam, mas que lhes constituíram. Trata-se de reconhecer, nos impulsos, aquilo que foi tecido às nossas costas, tecido pelas mãos da experiência social que continua a agir em nós." (SAFATLE, 2012, p. 165)

${ }^{22}$ Essa disposição de espírito é o resultado de um processo de formação, que permite, através da atividade do pensamento ou da reflexão, um "suprassumir e elevar ao universal" ("Aufheben [...] und Erheben ins Allgemeine", GW 14,1, $\$ 21$, Anotaçôes), universal que, para além da "universalidade 
Porém, além da oposição entre dever e querer sintomática de uma vontade entendida como autodeterminação - resultante de uma concepção unilateral da vontade como capacidade de autonomia, ante a pura indeterminação do seu primeiro momento -, a vontade como arbítrio também poderia conduzir, conforme lembra Safatle (2012, p. 159, grifo do autor.), a uma "atomizaçáo social”, decorrente de uma supervalorização da figura do indivíduo:

Quando hipostasiada, tal noção [PT: de "autonomia"] produz uma ideia de livre-arbitrio que, ao servir de guia para a ação política, acaba por levar a uma profunda atomização social resultante da elevação da categoria de 'indivíduo' a elemento central da vida social.

Ainda segundo Safatle, o fracasso do processo de liberação da dependência estrita à figura do indivíduo - processo importante à emergência de uma vontade capaz de se abrir à alteridade, indo além do modelo da vontade individual - resultaria na "[...] generalização de uma forma de ação incapaz de compreender sistemas de motivaçóes para além do quadro das vontades individuais" (SAFATLE, 2012, p. 166). Tal liberdade corresponderia à "autonomia de indivíduos isolados" (SAFATLE, 2012, p. 167).

Esse modelo de liberdade é característico das concepçóes contratualistas, para as quais as relaçóes sociopolíticas, a existência do Estado e de suas instituiçóes se fundamentariam, em última instância, na garantia de liberdades e direitos individuais. A vontade como arbítrio, concebida como o fato de "poder fazer o que se quer" (GW 14,1, $\$ 15$, Anotaçôes), própria a essa concepção utilitarista da vida em comunidade, ainda não corresponde, para Hegel, à verdade da vontade, visto que aí "ela ainda não se toma a si mesma como conteúdo e fim” (GW 14,1, \$15).

A distinção entre vontade livre e arbítrio é retomada, nos Cursos sobre a filosofia da história universal, como a distinção entre "vontade geral" ou "racional" e "a vontade e o arbítrio subjetivos":

formal" $(\$ 21)$, se transformou em uma "universalidade determinando-se a si mesma, a vontade, a liberdade" ("die sich selbst bestimmende Allgemeinheit, der Wille, die Freyheit", $\$ 21$.$) . Ver também, no$ Prefácio: "Der Mensch denkt und im Denken seine Freiheit und den Grund der Sittlichkeit sucht." (GW 14,1, p. 7) Sobre o papel desempenhado pela corporação para a formação da disposição de espírito ética, ver mais à frente, neste artigo. 
O essencial é que a liberdade, enquanto determinada pelo conceito, não tem por princípio a vontade e o arbítrio subjectivos, mas o discernimento da vontade geral, e que o sistema da liberdade é o livre desenvolvimento dos seus momentos. A vontade subjectiva é uma determinação inteiramente formal, na qual não reside o que a vontade quer. Só a vontade racional é este universal que em si se determina e desenvolve, desdobrando seus momentos como membros orgânicos (HEGEL, 1995, p. 123).

É importante ressaltar que essa "vontade geral" à qual alude Hegel, na Filosofia da história, se diferencia daquela defendida por Rousseau. Este, segundo a crítica feita por Hegel, na Filosofia do direito, reduziria o termo à vontade particular como "bel-prazer, opinião e arbitrariedade dos muitos" (GW 14,1, $\$ 281$, Anotaçóes, grifo do autor) ${ }^{23}$. Daí também a crítica de Hegel à noção de democracia ou de uma soberania do povo exercendo poder sobre o Estado, independentemente da "articulação do todo", como uma "representação desordenada" ou "massa informe" (GW 14,1, \$ 279, Anotaçóes) ${ }^{24}$. Nesse contexto, Hegel alerta para o perigo de uma rendição do Estado à arbitrariedade da vontade particular e à transformação dos poderes estatais em propriedade privada (GW 14,1, $\$ 281$, Anotaçóes) $)^{25}$. Aí, o universal não seria querido por $\mathrm{si}$, mas somente enquanto condição para a garantia $\mathrm{da}$ liberdade individual:

Hegel critica Rousseau por pensar a vontade a partir da noção de vontade individual, vontade que náo advém exatamente vontade geral, mas vontade comum, ou seja, associação de diversas vontades que não desejam um objeto universal, mas que desejam as condiçóes para a afirmação de seus sistemas particulares de interesses (SAFATLE, 2012, p. 168).

23 "als Belieben, Meynung und Willkühr der Vielen".

24 “ Das Volk, ohne seinen Monarchen und die eben damit nothwendig und unmittelbar zusammenhängende Gegliederung des Ganzen genommen, ist die formlose Masse, die kein Staat mehr ist und der keine der Bestimmungen, die nur in dem in sich geformten Ganzen vorhanden sind, - Souverainetät, Regierung, Gerichte, Obrigkeit, Stände und was es sey, mehr zukommt." (Grifo do autor). Sobre a conexão da problemática da liberdade (liberdade "objetiva" versus liberdade como livre-arbítrio) com a questáo da democracia, cf. KERVÉGAN, 2007, p. 253.

25 "Die Verfassung wird nämlich in einem Wahlreich durch die Natur des Verhältnisses, daß in ihm der particulaire Wille zum letzten Entscheidenden gemacht ist, zu einer Wablkapitulation, d. h. zu einer Ergebung der Staatsgewalt auf die Discretion des particulairen Willens, woraus die Verwandlung der besonderen Staatsgewalten in Privateigenthum, die Schwächung und der Verlust der Souverainetät des Staats, und damit seine innere Auflösung und äußere Zertrümmerung, hervorgeht." (Grifo do autor) 
Tal esforço, de reconhecimento do todo ético como condição necessária à fruição pacífica e duradoura das liberdades e direitos meramente subjetivos, é empreendido de maneira emblemática já por Hobbes. Ao propor a hipótese de um estado de natureza, o objetivo principal de Hobbes nada mais é do que o de demonstrar a condição desoladora na qual nos encontraríamos, se não pudéssemos contar com a força coercitiva do Estado e das instituiçóes sociojurídicas possibilitadas pelo mesmo. Assim, para Hobbes, as instituiçóes seriam um meio, o "menor dos maus", cuja tutela garantiria uma vida segura, do usufruto de direitos fundamentados pelo filósofo já no estado de natureza.

Ainda que com base nessa concepção a necessidade do Estado e de suas instituiçôes seja reconhecida, Hegel vê a relação de reconhecimento do indivíduo que se subjuga a esses mecanismos institucionais de maneira deficiente: a função das instituiçôes não se esgota, para ele, na garantia do direito dos indivíduos de perseguirem seus fins particulares, mas serve, indo além, à salvaguarda do bem comum, que os indivíduos, graças ao caráter formador promovido pelas instituiçóes, aprenderiam a adotar como seu próprio fim. No âmbito da sociedade civil-burguesa, tal tarefa seria assumida pelas corporaçóes, ponto que aprofundaremos mais à frente.

Até aqui, é importante retermos que Hegel, com a concepção de vontade livre que ele desenvolve em sua Filosofia do direito, aspira a uma unidade entre objetivo e subjetivo, entre aquilo que é dado, o ético incorporado pelas instituiçôes, e o indivíduo que, através de seu "saber, querer e agir" (GW 14,1, $\$ 142)^{26}$, garante sua efetividade, reproduzindo-o. Para o autor, entretanto, tal unidade só é bem-sucedida quando o indivíduo, enquanto subjetividade, reflete e reconhece nas instituiçóes a própria substância ética, desse modo não só a sabendo como condição de sua liberdade, todavia, ao mesmo tempo, a querendo, tornando-a objeto de sua própria vontade. Assim, em Hegel, o conjunto das estruturas éticas não pode ser visto como mera condição, mas tem, para além, de ser aspirado como fim. Só assim a vontade individual pode ser compreendida verdadeiramente como singularidade, enquanto união entre universalidade e particularidade $(\mathrm{GW} 14,1, \S 7)^{27}$, não restando, portanto,

\footnotetext{
26 "Die Sittlichkeit ist die Idee der Freyheit, als das lebendige Gute, das in dem Selbstbewußtseyn sein Wissen, Wollen und durch dessen Handeln seine Wirklichkeit, so wie dieses an dem sittlichen Seyn seine an und für sich seyende Grundlage und bewegenden Zweck hat, - der zur vorhandenen Welt und zur Natur des Selbstbewußtseyns gewordene Begriff der Freyheit." (Grifo do autor)

${ }^{27}$ A vontade livre como singularidade (Einzelheit) consistiria, antes, na unidade dos dois primeiros momentos nela contidos, da pura universalidade ou indeterminação e da determinação ou
} 
presa a esta última, mas abandonando seu caráter meramente privatista para se abrir a interesses mais gerais.

\subsection{Liberdade SOCIAL EM HONNETH}

É nesse mesmo sentido que, em $O$ direito da liberdade, Honneth parece caracterizar sua "liberdade social". No início da terceira parte da obra, intitulada "A realidade da liberdade", onde ele se refere às obrigaçóes impostas pelas diferentes esferas da liberdade social, reconhecidas através do assentimento reflexivo, Honneth (DL, p. 229) afirma:

O que há de peculiar em tais formas da autolimitação individual é que elas permitem aos indivíduos experimentar as obrigaçôes respectivas como algo que corresponda à realização de seus próprios fins, necessidades ou interesses; as limitaçôes morais não devem ser experimentadas diante dos outros como algo emperrado, que contrarie as inclinaçóes pessoais, mas como extensão e encarnaçáo social dos objetivos considerados constitutivos para a própria pessoa.

No entanto, abordando a noção de liberdade social, logo após a introdução da noção de liberdade intersubjetiva, Honneth lhe concede uma definição que parece se diferenciar desta última somente pelo acréscimo da necessidade de uma aceitaçáo que deveria ser concedida pelos indivíduos às instituiçôes, enquanto garantidoras e promotoras do "reconhecimento mútuo" característico da liberdade intersubjetiva (DL, p. 86). Logo, a especificidade da liberdade social consistiria no fato de que ela requer "instituiçôes de reconhecimento", as quais "são um conjunto de práticas de comportamento padronizadas", graças às quais os indivíduos podem "reconhecer-se reciprocamente em sua dependência um do outro" (DL, p. 86). Ou, ainda: "A liberdade representa sempre uma relaçáo de reconhecimento vinculada a uma instituiçáo" (DL, p. 88-89). Contudo, nesse caso, a liberdade social nada mais seria do que uma liberdade individual como arbítrio - que Hegel ligava, como víamos acima, a uma concepçáo de liberdade como capacidade de "poder fazer o que se quer" - e que, ao mesmo tempo, se sabe como condicionada pelas instituiçóes e pelos outros, isto é, como socialmente mediada: eu só posso obter a satisfação de meus interesses particulares, enquanto eu levo em conta

particularidade, tornando-se assim "a particularidade refletida em si mesma e através disso reconduzida à universalidade.” (GW 14,1, \$7) 
os interesses dos outros, disponibilizando, como membro da corrente do sistema dos carecimentos, os meios para sua satisfação.

Assim, dando enfoque à importância das instituiçóes e à sua tarefa de possibilitar "uma forma duradoura de realização recíproca de objetivos individuais" (DL, p. 102), Honneth parece, é verdade, atingir seu objetivo de combate às noçóes de liberdade negativa e reflexiva que negligenciam o papel das instituições, enquanto sua própria condição. Porém, ao limitar a função das instituições àquela de "condição", o autor negligenciaria a importância capital de um segundo aspecto assumido pelo universal, em Hegel, a saber, o de "fim". Por conseguinte, Honneth não conseguiria ir além de uma concepção meramente individualista de liberdade, que, entretanto, ele próprio critica.

Uma primeira crítica à concepção da liberdade social honnethiana é enunciada por Ludwig Siep, junto a Ayumi Takeshima, Nao Takeshima e Attila Karakus, em "Gutes und gelingendes Leben. Honneth über Anerkennung und Sittlichkeit”, publicado em 2004. O artigo é, portanto, anterior a $O$ direito da liberdade e remete sobretudo a Luta por reconhecimento (1992) e Sofrimento de indeterminação (2001). Segundo Siep, o conceito de eticidade presente nessas obras é ambivalente (SIEP et al., 2004, p. 61), sendo majoritariamente caracterizado como o conjunto das "condiçôes" para uma vida boa e bemsucedida ${ }^{28}$. Desse modo, as esferas éticas serviriam como a estrutura (Rahmen) para a realização de planos de vida individuais, feitos por cada um, de maneira isolada, com vistas a uma vida boa (SIEP et al., 2004, p. 65) ${ }^{29}$.

Uma outra concepção que, de acordo com Siep, corresponderia mais fielmente à concepção de eticidade de Hegel, consistiria ao contrário em tomar as esferas éticas como "fim" da vida boa. Nessa concepção, eticidade

\footnotetext{
${ }^{28}$ Apesar de se afirmar que Honneth caracterizaria a esfera da eticidade, frequentemente, "somente como o conjunto das condições para uma vida boa e bem-sucedida" (SIEP et al., 2004, p. 65, grifo dos autores), sustenta-se também que Honneth não responderia de maneira inequívoca, se essa esfera seria somente condiçấo da vida boa ou seu fim (SIEP et al., 2004, p. 65). Ainda segundo os autores, os quais se servem de trechos de Sofrimento em indeterminação para sustentar sua posição, Honneth interpretaria a Filosofia do direito de Hegel como uma teoria da justiça que se esforça em resguardar as condiçōes intersubjetivas ou esferas sociais necessárias à realizaçâo da liberdade individual (SIEP et al., 2004, p. 63). Cf. também Honneth, 2001, p. 31-32: aí Honneth entende a Filosofia do direito como uma tentativa de "exposição das condiçôes sociais para a autorrealização individual" (tradução de Tidre).

29 "Bezeichnet man mit dem Begriff der Sittlichkeit nur die Gesamtheit der Bedingungen für gutes und gelingendes Leben, wie es bei Honneth oft geschieht, so bieten die sittlichen Sphären nur den Rahmen für die Verwirklichung der individuellen Lebensentwürfe, die sich die einzelnen Mitglieder einer Gesellschaft im Hinblick auf ein gutes Leben machen."
} 
significaria não mais o conjunto das condiçôes da liberdade, mas representaria já a própria aplicação da vida boa e bem-sucedida. Nas palavras de Siep, "[...] se trata de decidir se as esferas éticas devem ser percebidas exclusivamente como algo instrumental, ou como portadoras de um valor intrínseco." (SIEP et al., 2004, p. 65). Ademais, Siep argumenta que, em Sofrimento de indeterminação, Honneth criticaria a atuação da corporação no interior da esfera da sociedade civil-burguesa como uma forma de reconhecimento ligada a interaçôes orientadas em valores, em oposição às transaçôes intermediadas pelo mercado. Segundo Siep, a crítica de Honneth à corporação se explicaria pelo esforço do mesmo em conceber as esferas éticas (família, sociedade civilburguesa e Estado) como "formais" ou "abstratas", de sorte a permanecerem "um horizonte aberto" (SIEP et al., 2004, p. 64), garantidor das condiçóes de realização de diferentes formas e projetos de vida - cujos fins seriam, pois, determinados por cada um de maneira particular ${ }^{30}$.

A crítica iniciada por Siep à concepção de liberdade honnethiana é retomada por Sven Ellmers, que a aplica, por sua vez, ao Direito da liberdade. Além de apoiar o ponto de vista de Siep, defendendo que Honneth apresentaria a função das instituições éticas de forma demasiado unilateral, isto é, meramente como "condiçôes", Ellmers (2015, p. 122 em diante) sublinha o caráter individualista da noção de liberdade social, em Honneth, que, desse modo, se afastaria da concepção de liberdade hegeliana: se, para Honneth, é a possibilidade de realização da liberdade individual - "pedra fundamental normativa de todas as ideias de justiça”" (DL, p. 37) ${ }^{31}$ - o critério a partir do qual se decide da racionalidade das instituiçóes existentes, para Hegel, estaria ligado à realização da "vontade livre", que, como víamos acima, não se reduz à vontade individual como arbítrio, mas à vontade que, além de sabe do universal como sua própria condição de possibilidade, também o quer como seu próprio fim. Assim, Hegel daria prioridade à universalidade frente à particularidade (ELLMERS, 2015, p. 125), não se deixando a liberdade hegeliana reduzir a uma liberdade meramente individual.

\footnotetext{
${ }^{30}$ Filipe Campello argumenta que, em $O$ direito da liberdade, ao contrário, Honneth se esforçaria justamente em combater teorias da justiça meramente circunscritas a princípios formais. Cf. Campello, "Do reconhecimento à liberdade social", p. 187.

31 "Na sociedade moderna vemos que a exigência de justiça só pode se legitimar se, de um modo ou de outro, a autonomia da referência individual for mantida. Não é a vontade da comunidade ou a ordem natural que se constituem pedra fundamental normativa de todas as ideias de justiça, mas a liberdade individual."
} 
Entretanto, como Ellmers (2015, p. 125) bem o destaca, a crítica à liberdade individual tem de ser bem entendida: não que as instituiçóes da eticidade em Hegel não deixem espaço à subjetividade. Bem ao contrário, na sociedade civil-burguesa, através da autonomia que esta ganha, a partir de sua separação do Estado, o direito de satisfação da particularidade se torna incontestável ${ }^{32}$. Contudo, Hegel também enuncia que, já na sociedade civilburguesa, o indivíduo é capaz de agir não somente conforme seus interesses particulares, mas também como "parte de um todo", passível de adotar também interesses de caráter mais amplo. Para Hegel, o problema não é, portanto, a liberdade individual, mas a tentativa de absolutização da mesma, na recusa da adoção de um conceito mais largo de liberdade, no qual o fim do querer e da atividade do indivíduo ensaia movimentos de universalidade, graças a um processo de formação que lhe permite de abrir-se à mesma. Nesse sentido, no parágrafo 187 da Filosofia do direito, Hegel censura não somente aqueles que idealizam o hipotético estado de natureza, no qual os homens seriam mais livres em razão de uma vida mais simples - na qual a vontade seria determinada exclusivamente por suas necessidades mais imediatas - mas também aqueles que consideram "as necessidades e sua satisfação, os prazeres e facilidades da vida particular" como o fim absoluto da vontade ${ }^{33}$, tratando assim a formação - Bildung enquanto processo de determinação da vontade por meio do trabalho - como mero meio para a obtenção de fins particulares.

Como veremos mais detalhadamente a seguir, a intenção de Hegel, de maneira oposta, é a de mostrar que, através do processo de formação, o indivíduo é capaz de abandonar não só a imediaticidade das necessidades naturais, passando a perseguir fins (e meios) que ele mesmo se dá, de acordo com sua vontade própria, mas que ele é igualmente capaz, ainda na sociedade civilburguesa, de ir além, determinando sua vontade por intermédio de interesses não só particulares, mas "particulares comunitários" 34 . O "comunitário" implicado nessa fórmula não deve remeter simplesmente à dependência mútua pela qual Hegel caracterizava o sistema dos carecimentos, isto é, como um sistema de "interesses comuns" (gemeinsame Interessen) de busca de

\footnotetext{
${ }^{32} \mathrm{O}$ direito da particularidade é, para Hegel, sem dúvida o traço mais marcante da modernidade, em contraposição ao paradigma antigo de uma eticidade que, perseguindo o universal, não sabe deixar espaço à particularidade - posiçáo que, de acordo com Hegel, se cristaliza na concepçáo platônica de Estado.

33 „die Bedürfnisse, deren Befriedigung, die Genüsse und Bequemlichkeiten des particulären Lebens u.s.f. als absolute Zwecke (GW 14,1, 187 , Anotaçōes, grifo do autor).

34 “Die gemeinschaftlichen besonderen Interessen” (GW 14,1, $\$ 288$, grifo do autor).
} 
satisfação de fins que remanescem, por sua vez, individuais, contudo, antes, como o formula Ellmers (2015, p. 124), de "interesse no comum" (Interesse am Gemeinsamen) ${ }^{35}$. Para Ellmers, ainda, esse aspecto seria negligenciado por Honneth, o qual também negligenciaria o papel importante assumido por instituições atuantes já na esfera do mercado, no processo de formação de tais interesses (ELLMERS, 2015, p. 124 em diante).

$\mathrm{Na}$ terceira parte deste artigo, propomos expor, primeiramente, como para Hegel esse processo de formação e de adoção de interesses mais abrangentes se inicia já no interior da própria sociedade civil-burguesa, possibilitando assim um retorno da eticidade a essa esfera, de forma imanente. Também intentamos realçar a função decisiva que aí desempenha a instituição da corporação. Levando em conta que Honneth reivindica para si a tese de uma eticidade imanente à esfera do mercado, propomo-nos igualmente abordar a maneira como ele sustenta sua posição, destacando os aspectos que eventualmente o afastariam de Hegel. É somente a partir dessa abordagem que estaremos habilitados a avaliar, além da questão da coerência com a qual Honneth retoma as teses hegelianas, a pertinência das críticas feitas por Siep e Ellmers.

\section{A IMANÊNCIA DA ETICIDADE NA ECONOMIA DE MERCADo}

\subsection{ETICIDADE IMANENTE OU ANTERIOR AO ACONTECER MERCADOLÓGICO?}

Para Hegel, a ideia de uma eticidade imanente à sociedade civilburguesa é estreitamente ligada à participação do indivíduo na instituição da corporação. É somente por meio da corporação que a universalidade, de mero condicionante da particularidade, se torna também seu objeto e fim:

$\mathrm{Na}$ medida em que, segundo a ideia, a própria particularidade faz da universalidade, que está em seus interesses imanentes, o fim e o objeto de sua vontade e atividade, o ético retorna como um imanente na sociedade civil-burguesa; isso constitui a determinação da corporação" (GW 14,1, $\$ 249) \cdot{ }^{36}$

\footnotetext{
${ }^{35}$ Ellmers afirma, referindo-se a Honneth: "Die sozialen Institutionen sind also nicht zwingend der eigentliche Gegenstand des freien Handelns; soziale Freiheit gründet in verzahnten oder gemeinsamen Interessen, nicht im Interesse am Gemeinsamen."

36 "Indem nach der Idee die Besonderheit selbst dieses Allgemeine, das in ihren immanenten Interesse ist, zum Zweck und Gegenstand ihres Willens und ihrer Thätigkeit macht, so kehrt das Sittliche als ein Immanentes in die bürgerliche Gesellschaft zurück; diß macht die Bestimmung der Corporation aus." (grifo do autor)
} 
A corporação oferece não somente a estrutura a partir da qual o indivíduo desenvolve aptidóes físicas e mentais necessárias à execução de uma determinada tarefa, mas também, e mais importante, torna possível o desenvolvimento de uma "disposição de espírito ética" (sittliche Gesinnung), constituída de qualidades morais, como a retidão e a honra (GW 14,1, $\$$ $207)^{37}$, que nascem das relaçôes de solidariedade e proteção mútua praticadas no interior dessa associação profissional. É somente graças à sua intervenção e através da sua influência que as relaçóes de dependência mútua do sistema dos carecimentos, meras relações de necessidade, transformam-se em relações éticas, formadoras da ulterior atuação do indivíduo como cidadão (HERZOG, 2015, p. 155$)^{38}$. Atuando na corporação, "bastiâo da integração social" (ELLMERS, 2015, p. 115), o indivíduo não se deixa mais reduzir à representação do homo economicus que age na esfera de mercado, de maneira isolada e meramente instrumental ou estratégica, se servindo dos outros somente como meio à garantia da satisfação de seus fins particulares.

Ao contrário, inserido na vida em comum de um grupo profissional, o indivíduo é - como já o era no interior da família-, antes de mais nada, "membro de um universal" (GW 14,1, $\mathbb{3} 303$, Anotaçóes) ${ }^{39}$, passível de adotar interesses que, como já o observávamos acima, para além de interesses meramente privados, são interesses particulares comuns ou comunitários (gemeinschaftliche besondere Interessen, GW 14,1, $\$ 288)^{40}$. Mais do que o compartilhamento dos

\footnotetext{
37 "Die sittliche Gesinnung in diesem Systeme ist daher die Rechtschaffenheit und die Standesehre, sich und zwar aus eigener Bestimmung durch seine Thätigkeit, Fleiß und Geschicklichkeit zum Gliede eines der Momente der bürgerlichen Gesellschaft zu machen und als solches zu erhalten, und nur durch diese Vermittlung mit dem Allgemeinen für sich zu sorgen, so wie dadurch in seiner Vorstellung und der Vorstellung Anderer anerkannt zu seyn." (grifo do autor)

38 "Although the ethos of the corporations is not yet the full ethos of the political citizenship, but limited to a smaller group, it is, for Hegel, an important step in the development of the latter. The individuals' preferences and identities are thus shaped in ways that prepare the ethos of the citizens - the citoyen, not the bourgeois - that Hegel describes as mark of the state. The very place in which people's preferences for a certain way of life and certains patterns of consumption are formed in civil society is also the place where they already learn to partly transgress their own interests, and to think in terms of a universality, however limited it may be."
}

39 "Mitglied eines Allgemeinen".

${ }^{40}$ Para uma análise mais detalhada do papel exercido pela corporação para a formação da disposição de espírito ética, crucial não só no âmbito da sociedade civil-burguesa, mas também no do Estado, como base do patriotismo necessário para um engajamento político vivaz, ver TIDRE, 2018, p. 128 em diante ("O devir ético da sociedade civil-burguesa"). É importante ressaltar também que a vivacidade com a qual os membros da sociedade civil-burguesa atuam no Estado é garantida, para Hegel, pela intermediaçấo dos Stände, corpos representativos que integram o poder legislativo, die gesetzgebende Gewalt. Ao lado do poder do monarca e do poder governamental, o poder legislativo representa, para Hegel, um momento fundamental na constituiçẫo do Estado. Os Stände seriam um 
mesmos interesses, é a própria vida em comum promovida pela corporação que é tornada fim (ELLMERS, 2015, p. 124-125) ${ }^{41}$, permitindo assim, para Hegel, o retorno do ético na sociedade civil-burguesa, ao qual ele aludia, ao caracterizar a corporação.

Tratando da questão da possibilidade da presença da eticidade, na esfera econômica, mediada pelo mercado, Honneth faz inúmeras referências aos modelos oferecidos por Hegel e Durkheim, de corporações ou associaçóes profissionais. Remetendo aos dois autores, Honneth relembra os esforços de ambos, na defesa de uma compreensão das normas promovidas pelas corporaçóes como imanentes a essa esfera, e não como mero aditivo ou como mecanismo coercitivo imposto de fora:

Nenhum dos dois autores deseja que esse sistema seja entendido por regras pré-contratuais e morais ao modo de um aditivo meramente normativo à economia de mercado, como se tivesse de se impor de fora, de maneira cega, os [sic. PT: "aos"] cálculos de lucro entretecidos." (DL, p. 335).42

$\mathrm{Ou}$, ainda, “[...] nenhum deles desejou que aquelas regras de ação précontratuais fossem entendidas ao modo de um complemento ao acontecer mercadológico que fosse meramente externo e de caráter normativo" (DL, p. 339).

No entanto, insistindo no caráter prévio ("pré-contratual”) que, segundo ele, as práticas propiciadas por instituiçôes corporativas assumiriam ante as relaçôes de mercado, a própria "consciência de solidariedade" (DL, p.

mecanismo de prolongamento dos diversos grupos existentes na sociedade civil-burguesa - distintos profissional (Gewerbestand, cuja instituição central é a corporação) ou socialmente (substantieller Stand) - e garantiriam que esses grupos pudessem se organizar na defesa política de seus interesses próprios (enquanto particulares comuns). “...in dem ständischen Elemente der gesetzgebenden Gewalt kommt der Privatstand zu einer politischen Bedeutung und Wirksamkeit. [...] Nur so knüpft sich in dieser Rücksicht wahrhaft das im Staate wirkliche Besondere an das Allgemeine an" (GW 14,1, $\$ 303$, destaque do autor). Honneth fecha os olhos para esse mecanismo de participação da sociedade civil-burguesa no Estado, optando por avaliar que a concepção do Estado esboçada por Hegel, fazendo "ampla abstração de todas as possibilidades de influência dos cidadãos" (2011, p. 583), sendo "centralista" e, assim, pouco apta a permitir instituiçôes promovendo uma relação "horizontal" entre os indivíduos (p. 485), teria "pouco interesse na real capacitação para a democracia" (idem).

${ }^{41}$ A crítica de Ellmers se estende também a Menke (1996) e Brudney (2010): assim como Honneth, eles não considerariam o fato de que a compreensão de Hegel da eticidade implicaria uma práxis conjunta. Segundo Ellmers, Hegel defenderia que o sentido e o fim das instituiçóes sociais (tanto a corporaçáo quanto o Estado) consistem em levar-se uma vida compartilhada, fim em si mesma.

42 "Keiner der beiden Autoren will dieses System von vorvertraglichen, moralischen Regeln als ein bloß normatives Additiv zur Marktwirtschaft verstanden wissen, so als müsse es erst von außen den blind ineinandergreifenden Nutzenerwägungen auferlegt werden” (HONNETH, 2011/2017, p. 328). 
335 e 338), a qual, para ele, existe na esfera de mercado "de maneira implícita" (DL, p. 338), parece dever ser compreendida náo como se originando a partir dessas próprias relações, mas como anterior às relações econômicas praticadas pelos indivíduos aí atuantes (DL, p. 334-335). Embora Honneth atribua igualmente a Hegel o seu entendimento das regras normativas como prévias às práticas características da economia de mercado - tratando-as, como visto acima, de "pré-contratuais" -, cremos que a exposição que fazíamos acima da concepçáa hegeliana acerca de um processo imanente, de formação de uma disposição de espírito graças à corporação, nos permita refutar essa posição.

Além disso, a posição de Honneth nos parece ambígua: ao mesmo tempo que, em algumas passagens, o autor enuncia que é "no acontecer do mercado" que "são constituídos os mecanismos que possibilitam influenciar os participantes individuais a perceber mais intensamente os interesses de outros atores no estabelecimento de seus interesses" (DL, p. 362) e ligando esses mecanismos às corporaçóes profissionais - o que levaria a crer na tese da emergência de práticas éticas em função do próprio "acontecer do mercado" Honneth afirma igualmente, um pouco antes no mesmo parágrafo, remetendo a Hegel e Durkheim, que a esfera de mercado só pode ser compreendida como ética, se fundamentada em "relaçóes de solidariedade anteriores ao mercado" (DL, p. 362).

\subsection{COEXISTÊNCIA ENTRE COMPORTAMENTO SOLIDÁRIO E COMPORTAMENTO INSTRUMENTAL}

Ao tratar do problema do comportamento pautado por puro proveito próprio, Honneth afirma - remetendo, mais uma vez, a Hegel - que, no intuito de se fazer respeitar as "normas externas ou prévias ao mercado" (DL, p. 353) ${ }^{43}$, este depositaria "todas as suas expectativas na anterioridade [Vorgängigkeit] de uma avaliação de valor recíproca” (DL, p. 353), empreendida pelos agentes econômicos, os Gewerbetreibenden (HONNETH, 2011/2017, p. 344-345), socializados nas corporaçóes. No mesmo sentido, Honneth escreve que a tarefa das corporaçôes, em Hegel (assim como dos grupos profissionais, em Durkheim) consistiria, "no plano abstrato de mecanismos de formação da consciência [Bewußtseinsbildung]" (DL, p. 360), em "fazer seus membros se recordarem das obrigaçóes de solidariedade que precedem o mercado" (DL,

43 “außer- oder vormarktlichen Handlungsnormen" (HONNETH, 2011/2017, p. 344). 
p. 360 ${ }^{44}$. Respeitada essa "condição", o direito de perseguição do lucro seria visto como legítimo: "Os atores econômicos devem ser antecipadamente reconhecidos como membros de uma comunidade cooperativa, antes que possam se conceder reciprocamente o direito de maximizar seu lucro no mercado." (DL, p. 358). Ou, ainda, "[...] os atores se propóem a continuar otimizando seu próprio proveito, mas tais estratégias são perseguidas por eles com maior ou menor consideração aos interesses dos outros participantes" (DL, p. 359).

Portanto, em face dessas afirmações, pode-se concluir que, para Honneth, uma concomitância de dois modos de agir, um solidário, outro meramente instrumental, é possível, o último sendo tomado por legítimo, na medida em que se deixaria inserir num quadro de regulamentaçóes, impedindo ou limitando seu caráter nocivo. Entretanto, essa posição - da defesa da existência prévia de relaçóes de solidariedade, externas ou coercitivas, diante do funcionamento mercadológico - parece entrar em contradição com a pretensão enunciada por Honneth de, nos passos de Hegel, defender a necessidade de um desenvolvimento imanente da consciência solidária, a partir das relaçôes econômicas. Segundo a concepção honnethiana, a perseguição de interesses econômicos parece ser colocada muito mais "ao lado", numa relação horizontal, ou mesmo hierarquicamente abaixo, de um comportamento solidário, este último atuando, para Honneth, como garantidor do funcionamento harmônico das interaçôes mediadas pelo mercado.

$\mathrm{Na}$ seção sobre a esfera do consumo, Honneth aprofunda a ideia de uma horizontalidade entre ambas os comportamentos, argumentando não somente que a reivindicação de bens julgados necessários pelos consumidores, de um lado, e a busca pela maximização de lucros visada pelos empresários, de outro, coexistem, mas que sua concomitância é condição necessária à realizaçáo de ambas:

[...] assim, os consumidores só poderiam realizar sua liberdade de satisfação de necessidades individuais ao se abrirem para a perspectiva de maximizaçáo de lucros mediante demanda num mercado, e os empresários, inversamente, só poderiam realizar sua maximizaçáo de lucros se efetivamente produzissem bens para aquela demanda de consumidores que tivesse originalmente acenado (DL, p. 392).

\footnotetext{
${ }^{44}$ Compare-se com a caracterização que Honneth dá das corporaçôes, mais adiante, como "escolas de socialização moral, nas quais se ensaiava publicamente burlar as estratégias de lucro capitalistas possibilitadas pelo mercado" (DL, p. 381).
} 
Essa posição permitirá a Honneth sustentar a tese segundo a qual a esfera de consumo mediada pelo mercado "[...] consistiria também numa instituição da liberdade social, na qual os diferentes interesses se entrelaçam de maneira complementar." (DL, p. 389). ${ }^{45}$ Para nós, a consequência mais relevante de tal posição é a defesa, por Honneth, da possibilidade de uma "correção meramente interna do mercado de consumo" (DL, p. 396) nos moldes de um "socialismo de mercado" (DL, p. 399) - em oposiçâo a uma economia planificada, a qual, em vez de corresponder a uma reforma da esfera do consumo mediado pelo mercado (defendida por Honneth), constituiria, ao contrário, mais radicalmente, "outro modelo de uma distribuição centralizada (igualitária) de bens produzidos sob a soberania de planejamento estatal" (DL, p. 396). ${ }^{46}$

Recusando esse último modelo, de uma "economia de planificação", Honneth aposta, por conseguinte, em uma via reformista, de um socialismo de mercado que ele caracteriza como uma organização social das condiçóes de mercado, propiciando a coexistência harmônica entre a satisfação ética das necessidades dos consumidores, de um lado, e a busca de valorização do capital por parte dos empresários, de outro. A possibilidade dessa coexistência se fundamenta, conforme Honneth, no fato de o mercado ser concebido por todos os seus participantes como meio de intercâmbio institucional, assim como na suposição de que consumidores e produtores se ajudariam reciprocamente na realização de seus respectivos interesses:

[...] se nos ativermos de modo reconstrutivo a movimentos e correntes sociais que tiverem exercido pressão para uma correção meramente interna do mercado de consumo, poderemos ver que seu ponto em comum, até o momento, terá sido a ideia de organizar socialmente as condiçốes de mercado, de maneira que estas pudessem, ao menos de modo aproximativo, satisfazer às exigências de liberdade social: as necessidades dos consumidores devem se adaptar de tal modo umas às outras que os rendimentos de capital a que os empresários aspiram se mantenham num contexto de acessibilidade coletiva e que a oferta dos bens pelos quais se anseia possa se realizar num sentido considerado ético, uma vez que o mercado foi concebido por todos os seus participantes como meio de intercâmbio institucional, em cuja função ambos os lados, consumidores e produtores, se ajudem reciprocamente na realização de seus respectivos interesses (DL, p. 396).

\footnotetext{
${ }^{45}$ Cf. também DL, p. 357: “[...] a liberdade de um se torna precondição para a liberdade do outro.”

${ }^{46}$ Compare-se também com a indicação de Hannes Kuch, segundo o qual Honneth se tornaria mais tolerante em relação à ideia de uma organização planificada da economia, em Die Idee des Sozialismus (KUCH, 2017, p. 178, nota de rodapé 3).
} 
Para Honneth, portanto, a relação de reconhecimento, subjacente, no sentido de anterior, às relaçôes mercadológicas de busca pelo lucro ou pela satisfação do mero interesse individual, garantiria a observância das regras normativas por parte de todos. Em uma situação na qual os empresários, dedicando-se à busca desenfreada pelo lucro, deixariam de levar em conta as demandas dos consumidores, seria preciso "lembrá-los" de que "eles estão obrigados a uma relação de reconhecimento instituída pelo mercado" (DL, p. 377-378), de modo que "a organizaçáo institucional dessas esferas" não deveria servir, como prossegue Honneth, "ao 'indivíduo', mas, para falar com Hegel, ao 'bem comum”' (DL, p. 397).

No presente artigo, não adentraremos na tese marxiana da contradição entre capital e trabalho assalariado, através da qual poderíamos pôr em xeque a afirmação de Honneth da possibilidade de existência de uma "ajuda recíproca” entre os diferentes agentes econômicos e, mais especificamente, da coexistência harmônica entre, de um lado, práticas mercadológicas orientadas ao "bem comum" e, de outro, uma produção visando de maneira incessante ao aumento do capital ${ }^{47}$. Aqui, nós nos limitamos a constatar que a premissa de base da qual parte Honneth - a saber, que os indivíduos, participando das relaçóes produtor-consumidor, na esfera do consumo, ou empregadoempregador, na esfera de mercado, já trazem consigo, de maneira prévia, uma consciência solidária ou cooperativa, necessária ao bom funcionamento dessa esfera - parece não só o distanciar de Hegel, mas mesmo contradizer a sua própria proposta, de uma moralização imanente ao mercado, com base nos processos que lhe são característicos. Como bem o formula Hannes Kuch,

\footnotetext{
${ }^{47}$ Sobre a crítica da tematização feita por Honneth da relação entre empresário e empregado como um harmonioso "Miteinander", ver DAHME; WOHLFAHRT, 2012, p. 115 (especialmente nota de rodapé 78). Conferir também a objeção feita a Honneth por Ellmers, o qual, remetendo-nos ao psicólogo Klaus Ottomeyer, afirma que o mercado náo propicia um comportamento cooperativo, solidário ou de confiança, mas, ao contrário, desconfiança, desonestidade, concorrência, hostilidade etc. Por isso, não haveria aí possibilidade de uma adesão de bom grado às regras morais (ELLMERS, 2015, p. 134-135). Além disso, também em Hegel, embora por razóes diferentes daquelas apresentadas por Marx, parece haver uma recusa da ideia de concomitância entre uma consciência de solidariedade, por um lado, e a busca por proveito próprio realizada de maneira isolada, para além dos moldes dados por associaçôes profissionais, de outro. A nosso ver, Hegel se esforça em defender, por meio de sua caracterização da corporação, uma espécie de abandono do puro proveito próprio através da primeira, enquanto, mediados pela corporação, os interesses de seus membros são sempre enformados pelas relaçóes éticas aí proporcionadas, e mesmo a riqueza, assim como a pobreza, ganham aí uma outra significação (GW 14,1, $\$ 253$, Anotaçôes). A teoria do valor marxiana, em especial a defesa de Marx do aspecto necessário da exploraçấo do trabalho produtivo no capitalismo, é mencionada, e refutada, por Honneth em $O$ direito da liberdade. Para tanto, o autor náo procede com uma exposição de argumentos próprios, mas se limita a remeter-nos a um escrito de Cornelius Castoriadis, originalmente publicado em 1978 (DL, p. 363-364).
} 
insistindo no aspecto de uma transformaçâo das açôes dos agentes econômicos e, assim, tornando mais explícita a contradiçáo que imputamos a Honneth (2017, p. 190),

[...] a estratégia da moralização interna tem por objetivo organizar os processos e estruturas ligados ao mercado de tal forma que as próprias açóes dos agentes atuantes nessa esfera sejam transformadas, de modo que estes, em seus posicionamentos e intençôes - ou para falar com Hegel, em sua "disposição de espírito ética" (sittliche Gesinnung, Filosofia do direito, $\$ 207$ ) - se tornem aptos a levar em consideração, de maneira solidária, a exigência e interesses de outros. ${ }^{48}$

Com efeito, a perspectiva hegeliana parece encorajar, muito mais do que a ideia de uma coexistência entre dois tipos de comportamento, aquela de uma transformação de um no outro. Em Hegel, é pela própria inserção do indivíduo em um sistema de divisão do trabalho visando a suprir, reciprocamente, as carências individuais, portanto, por sua atuação profissional, que é desencadeado o processo no qual o comportamento "egoísta" de cada participante se torna um comportamento solidário, aberto a interesses mais abrangentes, compartilhados entre os integrantes de uma mesma comunidade corporativa. Nessa perspectiva, a persistência de uma busca exclusivamente individual por lucro é vista por Hegel como perigosa, praticada justamente por aqueles que resistem a fazer parte de uma corporação, isolando-se e reduzindo sua atividade ao aspecto egoísta dos negócios.

A concentraçáo de riquezas nas mãos de indivíduos isolados provoca sempre inveja e resta sempre marcada pela ganância dos mesmos fora da corporação, de acordo com o diagnóstico antiliberal de Hegel [...]. Toda riqueza fora da corporação e da associação profissional é propriedade da populaça rica" (RUDA, 2011, p. 69-70, destaque do autor).

Ruda também assevera que a procura obstinada e eventualmente bem-sucedida pela obtenção de lucro faz do "jogador", isto é, daquele que aposta no arriscado "jogo" da sociedade civil-burguesa, um dos "happy few" que, através de sua riqueza, teria sua subsistência assegurada sem, no

48 Tradução de Tidre. Kuch nota que, na argumentação desenvolvida por Honneth em $O$ direito da liberdade, haveria uma "oscilação" (Schwankung) entre a moralização do mercado como resultante, de um lado, de um procedimento imanente às práticas próprias ao mesmo, e de outro, de acordos e normas prévios às práticas econômicas (KUCH, 2017, p. 186). Entretanto, Kuch não chega a entender tal oscilaçăo como uma contradição. 
entanto, a garantir por intermédio do próprio trabalho (RUDA, 2011, p. 74). Daí, aliás, a identificação feita por Ruda entre o Spieler e a "populaça rica" (der reiche Pöbel).

Entretanto, a despeito de Kuch nos dar a ocasião de tornar mais perceptível a proposta de Hegel, que aqui contrapomos à de Honneth, é igualmente Kuch que nos oferece uma objeção às críticas feitas por Siep e Ellmers a Honneth, as quais expúnhamos na segunda parte deste artigo. Como defende Kuch, e como se pode confirmar em $O$ direito da liberdade, Honneth vê, sem dúvida, a possibilidade de uma moralização imanente ao mercado, através da atuação das corporaçôes (KUCH, 2017, p. 191), que, nesse sentido, atuariam como verdadeiras "escolas da socialização moral" (DL, p. 380-381) ${ }^{49}$, ensinando seus integrantes a se preocuparem não só consigo mesmos, mas também com os outros, e a transformarem seus interesses, a ponto de tornarem suas intençóes e tendências mais universais (KUCH, 2017, p. 191).

Em "O mercado de trabalho", Honneth atribui às corporaçóes, do modo como tematizadas por Durkheim (DL, p. 436 em diante), a função de promoção dos "mecanismos discursivos", necessários para que os trabalhadores possam, aí influindo, "reconfigurar a esfera de produção mediada pelo trabalho" (DL, p. 440). Tais "tendências à socialização vindas de baixo do mercado de trabalho", pela "via cooperativa" (DL, p. 439), não só produziriam uma inflexão ante as regulações do mercado garantidas unicamente pelo poder coercitivo do Estado (DL, p. 437), mas tornariam ao mesmo tempo possível, "permitindo aos implicados uma influência recíproca na localização de interesses de cada um deles" (DL, p. 440-441), a formação de "objetivos de cooperação de caráter mais amplo" ou de "sentimentos de responsabilidade de caráter mais abrangente" (DL, p. 440).

\footnotetext{
49 "As corporaçôes de Hegel ou as cooperativas de produção que vieram depois eram também escolas da socialização moral, nas quais se ensaiava publicamente burlar as estratégias de lucro capitalistas possibilitadas pelo mercado". Uma formulação similar é utilizada por Oliver Nachtwey. O autor defende que a "invidualizaçáo negativa" característica do processo civilizatório conduz a uma "descoletivizaçáo" (Entkollektivierung), por meio do desaparecimento de "instituiçốes mediadoras" da sociedade civil, tais como comunidades locais, associações intermediárias, clubes, associaçóes de vizinhos. Para ele, a presença, outrora forte, dessas instituiçōes garantia que os indivíduos percebessem as dificuldades corriqueiras da vida como algo não estritamente individual, porém, compartilhado entre todos (geteiltes Schicksal). Também muito importante, aí os ressentimentos podiam ser articulados e formulados de maneira organizada. "Hier konnte man Ressentiments artikulieren, fand aber zugleich eine Form von Sozialisation, kollektiver Identität, sozialer Einbettung und eben auch sozialer Kontrolle". É nesse sentido que, de acordo com Nachtwey, essas instituiçóes podem ser entendidas como "Escolas da democracia e da cidadania" (Schulen der Demokratie und Zivilität).
} 
Fazendo referência aos escritos anteriores ao Direito da liberdade, a crítica de Siep pode ser julgada como pertinente, na medida em que chama a atenção para a deficiência de um entendimento demasiado formalista das instituições, as quais seriam assim reduzidas à função de condição de realização de objetivos formulados individualmente. Nesse sentido, poderíamos sustentar que Honneth, limitando-se a reconhecer a necessidade das instituiçôes somente pelo seu aspecto de condição, assumiria uma posição muito mais hobbesiana do que hegeliana. Todavia, ao levarmos em conta a importância reconhecida por Honneth às associaçóes profissionais, em $O$ direito da liberdade, a crítica que lhe é feita por Ellmers nos parece menos convincente. Ao retomar o fio argumentativo de Siep, aplicando-o agora ao Direito da liberdade, Ellmers parece ignorar que, nessa obra, como o defende Hannes Kuch, encontrando amplo respaldo em Honneth, as instituiçôes sofrem uma espécie de "inflação", passando a ditar conteúdos normativos e possibilitando aos indivíduos, dessa forma, não só a realização de projetos individuais, mas, para além, a formação e realização de interesses mais abrangentes.

\section{CONSIDERAÇÓES FINAIS}

Após a exposição da crítica, compartilhada por Honneth e Hegel, às concepçôes de liberdade jurídica e moral, além da apresentação da distinção feita por Hegel entre vontade livre e arbítrio, partimos para a abordagem das críticas feitas por Siep e Ellmers a Honneth, para os quais a compreensão honnethiana da liberdade social e das instituições éticas, garantindo sua realizaçáo, seria distinta da compreensão de Hegel das mesmas.

A liberdade, em Hegel, não se deixaria reduzir à liberdade individual à qual Honneth limitaria a liberdade social, assim como as instituiçôes que a garantem não poderiam ser vistas somente como condição para a realização de projetos individuais, mas, para além, deveriam, enquanto formadoras, tornar os indivíduos aptos a adotarem interesses mais gerais, surgidos a partir de experiências compartilhadas e possíveis, graças a essas mesmas instituiçóes. Só assim uma eticidade imanente à esfera do mercado - garantidora, aliás, de uma passagem ulterior à esfera do Estado - seria possível. Ante a função atribuída por Honneth às instituições em $O$ direito da liberdade, essa crítica, entretanto, parece náo se sustentar, visto que, nessa obra, se pode constatar a defesa feita por Honneth da importância, já na esfera do mercado, de instituiçóes que 
permitam a seus membros influir "de baixo" nas questóes econômicas e, o fazendo, forjar fins não só individuais, mas de caráter mais amplo e abrangente.

No entanto, a defesa dessa posição nos parece frágil, na medida em que Honneth defende igualmente a ideia de uma consciência de solidariedade ou de um acordo ético prévios aos processos surgidos a partir das relaçóes mercadológicas. Assim, julgamos que o caráter formador que Honneth reconhece, em $O$ direito da liberdade, às instituições (e mais especificamente às corporações, no que diz respeito à esfera do mercado), aspecto que tornaria forte sua tese de uma eticidade imanente, "vinda de baixo", acaba enfraquecido por sua defesa, ao mesmo tempo, de uma consciência ética precedendo as relações características dessa esfera. Para a superação dessa dificuldade, acreditamos que seria pertinente insistir, de forma inequívoca, na tese hegeliana de que o mercado, se é verdade que ele não é ético desde o início (tendo, antes, de se tornar ético), não poderia sê-lo, contudo, através de um acordo prévio, mas somente através de uma transformação, processo de formação inerente a suas próprias práticas.

TIDRE, P.; HELFER, I. Between honneth and hegel: from freedom to ethicity in freedom's right. Trans/form/ação, Marília, v. 43, n. 2, p. 215-246, Abr./Jun., 2020.

\begin{abstract}
The aim of the paper is to investigate the return to Hegel proposed by Axel Honneth in his work Freedom's right. Honneth rejects an approach that conceives of freedom only as negative or reflexive. Hence, he seeks to provide an alternative concept, which he assigns to Hegel using the term "social freedom". This concept of freedom, in opposite to the merely legal or moral one, should enable the recognition of the role played by the institutions as a condition in the process of its realization. However, despite the importance he gives to the institutions, Honneth is criticized for presenting an apparently too partial comprehension of them. The same happens to his definition of "social freedom", which, according to the critics, would consist in a merely individualistic conception of freedom, falling short of Hegel's understanding of this concept. An analysis of Hegel's thesis about an ethicity that would be immanent to the market sphere, also adopted by Honneth, will allow us to evaluate not just the connecting points or the divergences existing between them, but also the relevance of the criticism directed at Honneth.
\end{abstract}

KEYwORDs: Freedom. Institutions. Corporation. Bildung. Ethicity. 
SigLAS

$\mathrm{DL}$

GW 14,1

HONNETH, Axel. O direito da liberdade. Trad. Saulo Krieger. Sáo Paulo: Martins Fontes, 2015.

HEGEL, Georg Wilhelm Friedrich. Naturrecht und Staatswissenschaft im Grundrisse. Grundlinien der Philosophie des Rechts. In: Ders.: Gesammelte Werke, Bd. 14,1, hg. v. Klaus Grotsch u. Elisabeth Weisser-Lohmann. Hamburg: Meiner, 2009.

\section{REFERÊNCIAS}

ARNDT, Andreas. Geschichte und Freiheitsbewusstsein. Berlin: Eule der Minerva 2015.

BOER, Karin de: Kampf oder Anerkennung? Einige kritische Überlegungen zu Honneths Lektüre der Hegelschen Rechtsphilosophie". In: HETZEL, Andreas; QUADFLIEG, Dirk; SALAVERRÍA, Heidi (Hg.), Alterität und Anerkennung. Berlin: Nomos, p. 161177, 2011.

CAMPELLO, Filipe. Do reconhecimento à liberdade social: sobre 'O direito da liberdade' de Axel Honneth (Resenha). Cadernos de Ética e Filosofia Política, n. 23, 2013, p. 185-199.

DAHME, Heinz-Jürgen; WOHLFAHRT, Norbert. Ungleich Gerecht? Kritik moderner Gerechtigkeitsdiskurse und ihrer theoretischen Grundlagen. Hamburg: VSA, 2012.

ELLMERS, Sven. Freiheit und Wirtschaft. Theorie der bürgerlichen Gesellschaft nach Hegel. Bielefeld: transcript, 2015.

FRANZ, Günther (Hg.): Staatsverfassungen. Eine Sammlung wichtiger Verfassungen der Vergangenheit und Gegenwart in Urtext und Übersetzung. München: R.

Oldenbourg, 1964.

HEGEL, Georg Wilhelm Friedrich. Naturrecht und Staatswissenschaft im Grundrisse. Grundlinien der Philosophie des Rechts. In: Ders.: Gesammelte Werke, Bd. 14,1, hg. v. Klaus Grotsch u. Elisabeth Weisser-Lohmann. Hamburg: Meiner, 2009.

HEGEL, Georg Wilhelm Friedrich. Grundlinien der Philosophie des Rechts oder Naturrecht und Staatswissenschaft im Grundrisse. In: Ders.: Werke, Bd. 7, mit Hegels eigenhändigen Notizen und den mündlichen Zusätzen auf der Grundlage der Werke von 1832-1845 neu edierte Ausgabe. Redaktion Eva Moldenhauer u. Karl Markus Michel. Frankfurt a. M.: Suhrkamp, 1970 (Erstauflage 1968).

HEGEL, Georg Wilhelm Friedrich. Linhas fundamentais da filosofia do direito ou direito natural e ciência do Estado em compêndio. Trad. de Paulo Meneses, Agemir Bavaresco, Alfredo Morais, Danilo Vaz-Curado R.M. Costa, Greice Ane Barbieri e Paulo Roberto Konzen. São Leopoldo: Ed. Unisinos, 2010. 
HEGEL, Georg Wilhelm Friedrich. A razão na história. Introdução à filosofia da história universal. Trad. Artur Morão. Lisboa: Edições 70, 1995.

HERZOG, Lisa. Two Ways of Taming the Market. Why Hegel Needs the Police and the Corporations". In: BUCHWALTER, Andrew (Hg.), Hegel and Capitalism. Albany: State University of New York Press, p. 147-162, 2015.

HONNETH, Axel. O direito da liberdade. Trad. Saulo Krieger. São Paulo: Martins Fontes, 2015.

HONNETH, Axel. Das Recht der Freiheit. Grundriß einer demokratischen

Sittlichkeit. 3. Aufl. Berlin: Suhrkamp, 2017 (Erstauflage 2011).

HONNETH, Axel. Leiden an Unbestikmmtheit. Eine Reaktualisierung der Hegelschen Rechtsphilosophie. Stuttgart: Reclam Verlag, 2001.

HONNETH, Axel. Sofrimento de indeterminaçáo: uma reatualizaçáo da filosofia do direito de Hegel. Trad. de Rúrion Soares Melo. São Paulo: Editora Singular/Esfera Pública, 2007.

JAESCHKE, Walter. Hegel-Handbuch. Leben - Werk - Wirkung. Stuttgart: J. B. Metzler, 2003.

KERVÉGAN, Jean-François. L'effectif et le rationnel. Hegel et l'esprit objectif. Paris: Vrin, 2007.

KLOTZ, Christian. Manifestação e liberdade em Hegel. Veritas, Porto Alegre, v. 62, n. 1, jan.-abr., p. 116-129, 2017.

KUCH, Hannes. Die Sozialisierung des Marktes. Soziale Freiheit und Assoziationen bei Axel Honneth. In: ELLMERS, Sven; HERRMANN, Steffen (Orgs.). Korporation und Sittlichkeit: zur Aktualität von Hegel Theorie der bürgerlichen Gesellschaft. Paderborn: Wilhelm Fink, 2017, p. 177-204.

MÜLLER, Friedrich. Korporation und Assoziation: Eine Problemgeschichte der Vereinigungsfreiheit im deutschen Vormärz. Berlin: Duncker \& Humblot, 1965.

PEPERZAK, Adriaan Th. Hegels Pflichten- und Tugendlehre. Eine Analyse und Interpretation der Grundlinien der Philosophie des Rechts, \$\$ 142-156”. In: SIEP, Ludwig (Hg.), G.W.F. Hegel: Grundlinien der Philosophie des Rechts. Berlin: Akademie Verlag, p. 167-191, 2014.

RUDA, Frank. Hegels Pöbel. Eine Untersuchung der, Grundlinien der Philosophie des Rechts'. Konstaz: Konstanz University Press, 2011.

SAFATLE, Vladimir. A forma institucional da negação: Hegel, liberdade e os fundamentos do Estado moderno. Kriterion, n. 125, Jun, p. 149-178, 2012.

SIEP, Ludwig; TAKESHIMA, Ayumi; TAKESHIMA, Nao; KARAKUS, Attila. Gutes und gelingendes Leben. Honneth über Anerkennung und Sittlichkeit. In: HALBIG, Christoph; QUANTE, Michael (Hg.). Axel Honneth: Sozialphilosophie zwischen Kritik und Anerkennung. Münster: LIT, 2004, p. 61-65. 
TIDRE, Polyana. Individuum und Sittlichkeit. Die Beziehung zwischen Allgemeinheit und Besonderheit in Hegels Grundlinien der Philosophie des Rechts. Berlim: Wissenschaftlicher Verlag Berlim, 2018.

Recebido: 11/10/2018

Aceito: 29/11/2018 
TIDRE, P.; HELFER, I. 